Western University

Scholarship@Western

Aboriginal Policy Research Consortium International (APRCi)

2003

Stalking Aboriginal culture: the Wanda Koolmatrie affair

Philip Morrissey

Follow this and additional works at: https://ir.lib.uwo.ca/aprci

Part of the Other Feminist, Gender, and Sexuality Studies Commons

Citation of this paper:

Morrissey, Philip, "Stalking Aboriginal culture: the Wanda Koolmatrie affair" (2003). Aboriginal Policy Research Consortium International (APRCi). 330.

https://ir.lib.uwo.ca/aprci/330 
This article was downloaded by: [University of Western Ontario]

On: 16 December 2012, At: 07:16

Publisher: Routledge

Informa Ltd Registered in England and Wales Registered Number: 1072954 Registered

office: Mortimer House, 37-41 Mortimer Street, London W1T 3J H, UK

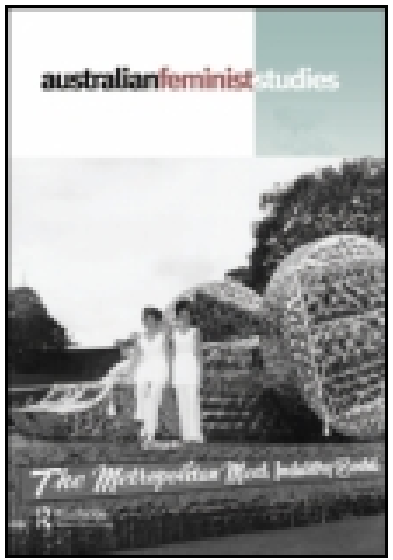

\section{Australian Feminist Studies}

Publication details, including instructions for authors and subscription information:

http:// www.tandfonline.com/loi/ cafs20

\section{Stalking Aboriginal culture: the Wanda Koolmatrie affair}

Philip Morrissey

Version of record first published: 03 J un 2010.

To cite this article: Philip Morrissey (2003): Stalking Aboriginal culture: the Wanda Koolmatrie affair, Australian Feminist Studies, 18:42, 299-307

To link to this article: http:// dx. doi.org/ 10.1080/0816464032000151775

PLEASE SCROLL DOWN FOR ARTICLE

Full terms and conditions of use: http://www.tandfonline.com/page/terms-and-conditions

This article may be used for research, teaching, and private study purposes. Any substantial or systematic reproduction, redistribution, reselling, loan, sub-licensing, systematic supply, or distribution in any form to anyone is expressly forbidden.

The publisher does not give any warranty express or implied or make any representation that the contents will be complete or accurate or up to date. The accuracy of any instructions, formulae, and drug doses should be independently verified with primary sources. The publisher shall not be liable for any loss, actions, claims, proceedings, demand, or costs or damages whatsoever or howsoever caused arising directly or indirectly in connection with or arising out of the use of this material. 


\title{
Stalking Aboriginal Culture: the Wanda Koolmatrie Affair
}

\section{PHILIP MORRISSEY}

\author{
Hoax, v.t., \& n. 1. Deceive, take in, (person) by way of joke. 2. n. Humorous \\ or mischievous deception.
}

Fraud, $n$. Criminal deception, use of false representations to gain unjust advantage; dishonest artifice or trick.

Imposition, (-z) $\boldsymbol{n} \quad \ldots$ piece of deception or advantage taking.

Utter, v.t. put (notes, base coin, etc.) into circulation. ${ }^{1}$

\section{History of a Deception}

Wanda Koolmatrie's novel My Own Sweet Time was published in 1994 by Magabala Books Aboriginal Corporation, an Aboriginal publishing house based in Broome, Western Australia. It is now known that Wanda Koolmatrie never existed, and My Own Sweet Time is believed to be the work, either jointly or individually, of two white Australian males known as John Bayley and Leon Carmen. As readers were informed in the biography provided by the publisher, Wanda Koolmatrie:

was born in the far north of South Australia in $1949 \ldots$

Removed from her Pitjantjara mother in 1950, she was raised by foster parents in the western suburbs of Adelaide. She married Frank Koolmatrie, who died several years later...

Koolmatrie was introduced to readers as a member of the Stolen Generation, thus as someone whose historical and familial connections had been dislocated by state policies of removing 'mixed-race' Aboriginal children from their families. ${ }^{2}$ The mysterious Frank Koolmatrie, 'who died', bears a name I've only encountered amongst Ngarrindjerie people of South Australia. ${ }^{3}$ In fact, shortly after the publication of My Own Sweet Time, when I asked a member of the Koolmatrie family if she knew Wanda Koolmatrie, she wasn't sure but didn't dismiss the possibility - testimony to the fracturing of Aboriginal families under colonialism and also to the willingness of many Aboriginals to claim displaced and disconnected relatives. The use of the name Koolmatrie was a subtle and clever move on the part of the book's author or authors: without having to make a direct claim on the Koolmatrie family the name functioned as another indication of the author's bona fides for the small number of readers capable of making the connection. The Koolmatrie family has shown considerable forbearance in tolerating the misuse of their name. 
My Own Sweet Time was reviewed favourably on release. Suzanne Donisthorpe in the Australian Book Review in April 1995 wrote:

So while Wanda's lack of anger or even curiosity about her people may seem strange and out of step with the current fashion, I suspect that Ms Koolmatrie is supremely unconcerned. She bears no grudges, she doesn't suffer from any illusions about who she is and in fact seems enviably well adjusted. ${ }^{4}$

There were other good reviews, and in April 1996 Wanda Koolmatrie was the recipient of the Nita May Dobbie Literary Award, a cash prize of $\$ 5,000$ for the best first novel by a female writer.

In spite of this, it seemed that My Own Sweet Time would sink into anonymity, until Leon Carmen, a white Australian male, claimed on 12 March 1997 that he was the author of My Own Sweet Time. ${ }^{5}$ Carmen went public after an attempt to publish a second Wanda novel was stalled by the adamant insistence of Magabala Books Aboriginal Corporation that the author be produced ${ }^{6}$ His revelation seemed opportunistically timed to ride on the current wave of anti-Aboriginal feeling in Australian politics and Australian public life. ${ }^{7}$ In March 1997 it was also revealed that Elizabeth Durack, a senior member of the patrician Durack family, was the creator of the Eddie Burrup paintings (works purportedly executed by an Aboriginal elder from the Kimberley, one of which had been hung in an exhibition of Aboriginal art at Tandanya, South Australia's Aboriginal Culture Centre). ${ }^{8}$ The veracity of Aboriginal testimony with respect to sites of cultural and spiritual significance on Hindmarsh Island had also been a matter of controversy for a number of years, with a Royal Commission convened by the South Australian State government determining in December 1995 that evidence of sacred sites on the island had been fabricated. ${ }^{9}$

I played my own part in the Koolmatrie affair and this article puts on record some facts and perspectives of possible use for future researchers.

\section{Personal Involvement}

I sensed the urgency of Magabala Books Aboriginal Corporation's request for a reader's report: it was the excitement of a small press anticipating a My Place-style critical and commercial success with an exciting first novel by a hitherto unknown Aboriginal writer. In response, I wrote in a very hurried report:

If it was published I'd teach it ... Because of its quirkiness I find myself asking: who is Wanda Koolmatrie? Is it some hoax? All of this is an indictment of the expectations we have of Aboriginal literature.

One conventional piece of advice I gave at the time was that readers would be disturbed by the way the author raised questions relating to her Aboriginality in the early chapters, but didn't pursue these issues of origins, difference, or heritage with any set plan or seriousness. The book was released with a back-cover blurb composed of laudatory comments by Dorothy Hewitt: 'This is the lively, gutsy story of an urban Aboriginal girl making it in the tough city counter culture of the mid-sixties ... It could be the start of a new genre.' And an excerpt from my reader's report (without my permission): 'I felt an uncomplicated pleasure when reading this book ...'. The pleasure I felt was genuine. The protagonist was likeable, if eccentric, and the novel evoked some of the best aspects of 1960s Australia.

Notwithstanding my own readerly enjoyment, the effect of My Own Sweet Time on conceptions of Aboriginal writing was minimal, and I decided to try and help publicise 
what I thought was an original and challenging work. Before doing so I prudently checked once more whether the author was Aboriginal and spoke to Magabala Books Aboriginal Corporation's then editor Bruce Simms, who passed on to me the telephone number of John Bayley, Wanda Koolmatrie's agent. The following is my record of the two telephone calls I made:

telecon Bruce Simms

2nd book of WK's in pipeline - has applied for grant for her - has yet to meet her. $3 / 11 / 95$.

telecon John Bailey [sic] - Agent for W. Koolmatrie assured me W.K. is Abl (part Abl) - will pass on my number to her and let her know I'd like to meet her. 3/11/95.

Presumably I was one of any number who wanted to meet Wanda Koolmatrie. (Carmen, in announcing the deception, said that at least there was one question that would no longer be asked: 'Where's Wanda?') ${ }^{10}$ I then proceeded with a 'Rolling Column' for the Australian Book Review in which I stressed the book's necessary significance when considered in relation to prevailing dogmatics of Aboriginal writing. ${ }^{11}$ My Own Sweet Time, however, had no further critical impact until Leon Carmen claimed authorship. Carmen was the public face of the deception and presented himself as a 'bloke', middle-aged and ordinary, relaxing by playing pool games with his friend and co-conspirator, John Bayley. ${ }^{12}$ It is unclear, from the evidence publicly available, who actually wrote My Own Sweet Time but there are those who believe that Bayley, rather than Carmen, is its author. For instance, when confronted with claims that Carmen was the author, Bruce Simms said: 'They've been lying for three years - now everybody suddenly thinks they're telling the truth. ${ }^{13}$

I recall seeing Carmen interviewed by an indulgent current affairs show host shortly after his revelation. It seemed to me that he thought the 'hoax' would blow over, and the general reaction would be one of amusement, leading to a publishing contract under his own name. He may well have been encouraged in this by Australian society's prevailing contempt for Aboriginals and for intellectuals, as well as by the host, who seemed to view it as one more humiliation for a pompous and foolish literati caught trading in fools' gold.

\section{The Book's Importance}

At the time of the publication of My Own Sweet Time Aboriginal writing was at its limit. A once-vigorous and enlivening politics of Aboriginal writing had become intellectually repressive and a critical hegemony had been established, in some ways best described by the term 'repressive authenticity'. What had been a necessary strategy for establishing the political basis of Aboriginal writing in the face of residual Leavisite critical methods had become a cultural dead-end.

Oodgeroo's Eleven Commandments of Aboriginal writing and Mudrooroo's Fanonderived schematisation of three phases of Aboriginal writing ('from assimilated and culturally alienated forms of writing by Aboriginals to an activist literature') were the dominant critical paradigms. ${ }^{14}$ Aboriginal writers were, it seemed, under pressure to produce representative works which spoke for an essential or universal Aboriginal condition. In a context with some historical parallels, Kobena Mercer observed that black filmmakers in Great Britain were given the right to speak, on the implicit understanding that they 'represent' and 'speak for' the total black community. ${ }^{15}$ As a 
result of Mudrooroo's influential theory of textual Aboriginality (that is, that a work written by an Aboriginal writer could be evaluated as to the extent of the 'Aboriginality' it contained), there emerged what could be termed an 'indexing of otherness'. ${ }^{16}$ Performative and declaratory forms of Aboriginality were required of Aboriginal texts. This dogmatic and static notion of Aboriginality ignored the fact that Aboriginals were, even more so than most communities, 'people in transition', occupying ever more complex positions and significations in Australian society. And even as Aboriginal writing acknowledged this implicitly in some of its practices, its over-determined theory suppressed the fact that Aboriginals were engaged in self-fashioning and a remaking of themselves as a community and as individuals. ${ }^{17}$ To an extent this was helped by Australian scholars' sometimes unproblematised use of concepts of 'resistance literature' and postcolonial theory to frame and interpret Aboriginal literature. Because of its authoritarian nature, this ideology of Aboriginal writing resisted modification through self-critique and dialectic in the scholarly field. Instead, it was shattered through exposure in the public sphere. In the most notable instance the authenticity of Mudrooroo's own Aboriginality came under serious challenge in 1996, and his influence as an Aboriginal writer and critic ended shortly thereafter. ${ }^{18}$

Something of the tension of that time is evident in the following excerpt from the lecture notes I used when I first started to teach My Own Sweet Time in 1996:

Is the book a hoax? I don't know, but it's the sort of book doctrinaire postcolonial theorists must exclude from their Aboriginal resistance thesis or ignore.

And when we think about My Own Sweet Time we find that the book disrupts our conventional reading strategies. We have established writing in a certain framework, and the book through its content and what we assume textually is the author's Ablty [sic] deconstructs it. It traps us into making the premature judgement. Questions are left unanswered: is it a novel based on her life? - is it her life? - is it purely fictional? ... the power of assumptions that the narrator's name is Wanda. But My Own Sweet Time isn't validated by or authorised by the author's presence or experience - we know little about her. If there would not be outrage at the perpetration of such an imposition we might well suspect a hoax. How can someone apparently trifle with something so full of meaning for Aboriginal society? - the fact of being taken away. The uncertain status of the book puts a stop to what Spivak calls the 'information extraction' style of reading Third World/minority literature.

There is a tradition of narrative discourse which Aboriginal writers for better or worse are now inheriting and limited by: a certain mode of representing Aboriginals which may become as stereotyped as the portrait shots of elders and the desert warrior standing on one leg.

The complex and challenging nature of the Aboriginal dance and theatrical productions presented as part of the Festival of the Dreaming in September 1997 signalled publicly that Aboriginal art and culture as a whole had moved on from the dogmatics which had constrained Aboriginal writing. The Festival of the Dreaming was the first of a series of cultural festivals convened in the lead-up to the Sydney 2000 Olympic Games and featured an unprecedented number of risk-taking, original productions by Aboriginal artists. ${ }^{19}$ This was in large measure due to the creative vision of the Festival's Executive Producer, Rhoda Roberts, and her willingness to make value-driven choices. In a speech delivered after the Festival had concluded, Roberts expressed her disappointment at the 
quality of some of the scripts originally submitted for consideration as performances'kitchen sink drama, very mediocre'- and pointed out the dangers of complacency for Aboriginal artists. ${ }^{20}$ Roberts underscores the importance of internal critique as a condition for a robust contemporary Aboriginal culture.

\section{Critique and Effects}

Once Carmen had announced the Koolmatrie deception it became a vertice for a range of issues and effects connected with the authenticity of Aboriginal cultural production and writing. The following is a summary of some of them:

\section{Practical Consequences}

The publication of My Own Sweet Time by Magabala Books Aboriginal Corporation made demands on funding intended for Aboriginal authors, and took priority over other manuscripts that Magabala Books Aboriginal Corporation had planned for publication. In the extreme instances, the consequent delay in publication could well have meant that elderly Indigenous authors may not have lived to see their manuscripts in print.

\section{Aboriginal Privilege}

Several journalists and newspaper letter writers took the Carmen-Bayley deception as proof of the special privileges available to Aboriginals. In discussing Mudrooroo's assumption of an Aboriginal identity, Peter Craven suggested that because people have been persecuted as a result of their race, individuals shouldn't seek to gain advantages by claiming to belong to an oppressed race. ${ }^{21}$ This applies more pertinently to Carmen and Bayley. The fact is that 'Race matters in a race-conscious society - even if we periodically entertain ourselves with the absurdity of racial classifications. ${ }^{22}$

\section{Traditional Culture}

Kaye Mundine, Chair of the National Indigenous Arts Advocacy Association, invoked traditional Aboriginal gender demarcations when responding to Carmen's revelations. She was reported as saying: 'As an Aboriginal woman, if I pictured myself as an Aboriginal man I would be lucky not to be punished within 24 hours. ${ }^{23}$ (It has to be noted, however, that arguments grounded in tradition have little traction or relevance in a secular humanist society.)

\section{White Privilege and Cultural Transvestism}

In its mildest form, white intellectuals have the freedom to choose when and how to engage with Aboriginal issues without endangering their cultural notation as white writers.

In the extreme instance of assuming an oppressed minority's identity Gayle Wald has observed that:

White people (especially white men) traditionally have enjoyed a greater liberty than others to play with racial identities and to do so in safety, without permanent loss or costs. White sanction to 'pass' inevitably hinges on the 
structure of race itself, that is, on a system in which some racial identifications are more rigidly organized and maintained than are others. ${ }^{24}$

With respect to Carmen and Bayley's creation of a fictional Aboriginal identity, it is pertinent to note that neither of them showed any of the symptoms common to people who covet Aboriginal identities - and neither had any doubts about the social and intellectual centrality of their whiteness. Certainly there was none of the pathos often observable in other cases of individuals wanting to become Aboriginal.

\section{Postcolonial Envy}

Elizabeth Webby, Professor of Australian Literature at the University of Sydney and one of the judges for the Dobbie Award, said: 'There is this sense of wanting to belong to the country. I am Anglo-celtic from a family which has been in Australia for a long time. You don't have an allegiance to another culture ... We are the group which has had an identity taken away. ${ }^{25}$ Webby's statement discloses the victimage, naivety and selfabsorption which can make settler society such a threat to Aboriginal cultural integrity. In response to this, some Aboriginals have seen the relation of settlers to Aboriginal culture as a predatory one, in which the theft of Aboriginal culture will follow on the theft of Aboriginal land.

\section{Witnessing}

Contemporary Aboriginal culture, notwithstanding its aesthetic value, has been recognised as one of the most effective forms of politics used by Aboriginal communities. Perkins and Fink, for instance, have noted with respect to fine arts that the 'phenomenon of Aboriginal art has made it less easy to push Aboriginal people around'. ${ }^{26}$ By impersonating Aboriginals and making Aboriginal culture, one can attempt to show that there is nothing there. Vivien Johnson, who has done outstanding work in combating the fraudulent misrepresentation of Aboriginal culture, described those non-Aboriginals falsely uttering Aboriginal art 'as perjurers using the forum of Aboriginal art to bear false witness'. ${ }^{27}$ Johnson writes: 'I believe that the effect of literary and artistic fraud in Aboriginal art ... is to undermine this capacity of Aboriginal art to bear cultural witness: to speak its own truths to mainstream audiences. ${ }^{28}$

\section{Authenticity and Value}

What is the status of My Own Sweet Time now that it is known to be written by a non-Aboriginal author or authors? The quirkiness and surprisingly 'un-Aboriginal' behaviour and life-solutions of Wanda, the protagonist of My Own Sweet Time, are neither surprising nor significant when issuing from the pen of a settler male outside the Aboriginal experience of race, gender and, more pointedly, the Stolen Generation. Mark Sagoff points out that: 'The authentic and the inauthentic are aesthetically different not necessarily because they look different but because they are different things. ${ }^{29} \mathrm{He}$ goes on to argue:

Appreciation is historical because it identifies an artwork as the result of a particular process; it is relational in that it judges a work ... in the context of others similar to it in period, place and kind. Appreciation is cognitive, finally, 
because our feelings make us aware of the properties (not merely the surfaces) of things. ${ }^{30}$

\section{International Practices}

The Draft United Nations Declaration on the Rights of Indigenous Peoples declared that:

\section{PART III}

Article 12

Indigenous peoples have the right to practise and revitalize their cultural traditions and customs. This includes the right to maintain, protect and develop the past, present and future manifestations of their cultures, such as archaeological and historical sites, artifacts, designs, ceremonies, technologies and visual and performing arts and literature, as well as the right to the restitution of cultural, intellectual, religious and spiritual property taken without their free and informed consent or in violation of their laws, traditions and customs.

Notwithstanding what I believe are limitations in the manner in which the United Nations defines and imagines Indigenous communities, declarations such as the above function as guides for acceptable ethical behaviour and legal process by nation-states. Any consideration of issues of cultural appropriation should also take account of them as a point of orientation.

\section{Trade Practices Act 1974}

After the outing of Mudrooroo, Frank Moorhouse wrote: 'If publishers cannot guarantee the authenticity of their author, they are not only fools, they are engaging in shoddy trading. ${ }^{31}$ Moorhouse's point is well made, and relevant sections of the Trade Practices Act include sections 52 (misleading and deceptive conduct) and $53 \mathrm{c}$ and d (false and misleading representations) and 55 (misleading conduct as to the nature and character of goods). ${ }^{32}$ In a recent intervention, the Australian Competition and Consumer Commission restrained Australian Icon Products Pty Ltd, a leading Australian manufacturer of 'Aboriginal-style souvenirs', from referring to its products as 'authentic' and 'Aboriginal art' unless it reasonably believed they were made by Aboriginals. ${ }^{33}$

\section{Final Reflections}

Following Bayley's acceptance of the Nita May Dobbie Award on behalf of Wanda Koolmatrie, he was charged by New South Wales police with 'making a false and misleading statement involving the author Wanda Koolmatrie who was a fictitious person invented by author Leon Carmen and Mr Bayley. ${ }^{34}$ The charge against Bayley was heard in the Downing Centre Local Court in Sydney on 12 March 1998, when presiding magistrate Geoff Brad dismissed it on the grounds that there was "no prima facie case" to support the fraud allegations. ${ }^{35}$ Criminal law has its own logic, but magistrate Brad's reasoning is puzzling for the layperson: after all it was Bayley who, apparently of his own free will, deceived Magabala Books Aboriginal Corporation and the sponsors of the Nita May Dobbie Award.

If there are no legal sanctions applicable to Bayley there is still the public domain, and 
Magabala Books Aboriginal Corporation was, I believe, mistaken in not being more explicit in putting the details of the matter on the public record. The press release of the Management Committee of Magabala Books Aboriginal Corporation spoke of the 'elaborate web of deceit' generated by Bayley in order to convince the publisher that the author of My Own Sweet Time was Aboriginal. Something of the nature of the tales Bayley presumably told Magabala Books Aboriginal Corporation, however, can be gleaned from press reports. Gerard Henderson writes that Bayley told Magabala that My Own Sweet Time was non-fiction. ${ }^{36}$ The Advertiser reported that Bayley had been charged by New South Wales police because 'he was the person who kept the hoax alive by supplying false statements to the employees of Magabala Books Aboriginal Corporation'. ${ }^{37}$ The Advertiser also stated that Bayley informed them that he was accepting the Nita May Dobbie Literary Award on behalf of Wanda Koolmatrie because she was "in England and could not return for the award ceremony because of "complications" with her Algerian Muslim boyfriend'. ${ }^{38}$

The intricate nature of the deception suggests that for at least one of the deceivers the psychological pay-off was neither 'blokey' nor uncomplicated. A clue might be found in the character of Bayley himself, whose favourite literary forger is reportedly Thomas Chatterton, the eighteenth-century utterer of the Rowley poems which were initially acclaimed then rejected as a forgery by Horace Walpole. When the deception was made known I felt there was something pathological in Bayley and Carmen's creation of the figure of Wanda Koolmatrie: a private fantasy that should have been kept private rather than trawled in public. Further to this was the fact that in order to make it happen they had to use the historical fact of the Stolen Generation as a deus ex machina. At the time, the best framework I could think of in order to comprehend the actions of Bayley and Carmen was that of the stalker. In illustrating the connection between gratuitous cultural impersonation and stalking I've often used an excerpt from the brilliant 1992 film Single White Female in which a disturbed girl stalks her flatmate, mimicking her clothing and hair style, before ultimately taking her hostage and setting out to reverse matters by making the flatmate look like her. It seemed that the deception was one more sad symptom of a section of settler Australia's mediocrity: an emptiness that covets and envies Aboriginal sovereignty as much as it despises Aboriginals. With the passage of time I'd now like to believe that the motives of Bayley and Carmen were probably less pathological, and more a case of an initial deception getting out of hand. I ground this hopeful interpretation in a reading of My Own Sweet Time itself, a novel that certainly isn't written in a tone of contempt and bitterness, but rather entextualises a message of respect and agency.

My Own Sweet Time, readerly, upbeat, with admirable representations of artistic vision, courage and agency, but fraudulently uttered, now sits in Baillieu Library's Special Collection consigned to history. It's still an important part of my Aboriginal Writing course; but it's a lecture based on a text that no one's expected to read.

\section{NOTES}

1. Definitions taken from The Concise Oxford Dictionary of Current English (Oxford University Press) Oxford, 1964.

2. This historical circumstance was, of course, convenient for the deception.

3. A search of the Melbourne White Pages telephone book failed to turn up anyone with the name Koolmatrie.

4. Suzanne Donisthorpe, 'A Positive New Voice', Australian Book Review, April 1995, p. 28.

5. Andrew Stevenson and Ava Hubble, 'My Sweet Hoax', Daily Telegraph, 12 March 1997, p. 1. 
6. Stefanie Balogh, 'Aboriginal Book Hoax Angers Publisher', Australian, 13 March 1997, p. 1.

7. The Paul Keating-led federal Labor government lost office in March 1996 to a radical-conservative Liberal government led by John Howard. The Howard government set about reversing many of the Keating government's policies and programs relating to Aboriginals-an interest group it perceived as having disproportionate influence.

8. See Sian Powell, 'The Durack Dynasty', Australian, March 1997, p. 13.

9. See Diane Bell, Ngarrindjeri Wurruwarrin (Spinifex Press) North Melbourne, 1998; and Margaret Simons, The Meeting of the Waters (Hodder Headline) Sydney, 2003.

10. Leon Carmen, 'A Fake Called Wanda', Herald Sun, 15 March 1997, p. 17.

11. Philip Morrissey, 'Rolling Column', Austratian Book Review, February/March, 1996, p. 27.

12. Carmen, 'A Fake Called Wanda', p. 17.

13. Peter Lalor, 'Publisher Pulls Plug on Hoaxer', Daily Telegraph, 15 March 1997, p. 7.

14. See Mudrooroo Narogin, Writing from the Fringe: a Study of Modern Aboriginal Literature (Hyland House) South Yarra, 1990, pp. 21-3; and Philip Morrissey, 'Aboriginal Writing' in Sylvia Kleinert and Margo Neale (eds), The Oxford Companion to Aboriginal Art and Culture (Oxford University Press) South Melbourne, 2000, pp. 314-15.

15. Kobena Mercer, 'Recoding Narratives of Race and Nation' in Kobena Mercer, Welcome to the Jungle: New Positions in Black Cultural Studies (Routledge) New York, 1994, p. 92.

16. William B. McGregor, 'Writing Aboriginal: Oral Literature in Print', Median, vol. 8, no.1, 1989, p. 51.

17. The appropriation of the autobiographical method as a means of recording Aboriginal histories and experience, for instance, stands out as one of the Aboriginal community's most significant cultural innovations in the late twentieth century.

18. See Victoria Laurie, 'Identity Crisis', Weekend Australian Magazine, 20-21 July 1996, pp. 28-32.

19. The Festival was also noteworthy for performance involving Aboriginal and settler collaborations.

20. See 'A Passion for Ideas: Black Stage', Third Rex Gramphorn Memorial Lecture, Belvoir Street Theatre, Sydney, 23 November 1997, < http://www.media.euro.apple.com/en/livepage/ > .

21. Peter Craven, 'Readings', Australian, 9 April 1997, p. 38. (Mudrooroo's apparent assumption of an Aboriginal identity has significant mitigating factors.)

22. Katya Gibel Azouley, 'Outside Our Parents' House: Race, Culture, and Identity', Research in African Literatures, vol. 27, no. 1, Spring 1996, p. 131.

23. Debra Jopson, 'Writing Wrongs', Sydney Morning Herald, 15 March 1997, p. 38.

24. Gayle Wald, "A Most Disagreeable Mirror": Reflections on White Identity in Black Like Me' in Elaine K. Ginsberg (ed.), Passing and the Fictions of Identity (Duke University Press) Durham, NG, 1996, p. 162.

25. Jopson, 'Writing Wrongs', p. 38.

26. Hannah Fink and Hettie Perkins, 'Writing for Land', Art and Australia, vol. 35, no. 1, 1997, p. 61.

27. Vivien Johnson, 'Never Mind the Burrup, Here's the Balandas', manuscript.

28. Johnson, 'Never Mind the Burrup, Here's the Balandas'.

29. Mark Sagoff, quoted in Gregory Currie, An Ontology of Art (Macmillan) London, 1989, p. 93.

30. Sagoff, quoted in Currie, An Ontology of Art, p. 93.

31. Frank Moorhouse, 'Write and Wrong', Age, 16 August 1996, All.

32. Michael McMahon, in Copyrites: Aboriginal Art in the Age of Reproductive Technologies, Touring Exhibition Catalogue, 1996.

33. 'ACGC Obtains Interim Orders against Aboriginal-style Souvenir Dealer', MR 64/03, 4 April 2003.

34. Kylie Keogh, 'Hoax Author's Agent Cleared of Fraud', Advertiser, 13 March 1998, p. 25.

35. Keogh, 'Hoax Author's Agent Cleared of Fraud', p. 25.

36. Gerard Henderson, 'Not Another Ern Malley', Age, 18 March 1997, p. A15.

37. Keogh, 'Hoax Author's Agent Cleared of Fraud', p. 25.

38. Keogh, 'Hoax Author's Agent Cleared of Fraud', p. 25. 
